\title{
Black Theology of Liberation and the Economy of Life
}

\author{
VS Vellem
}

\begin{abstract}
The original sin of capitalism is its relationship with racism, a repugnant expression of White supremacy, therefore to engage the metaphysics of neoliberal economics one must have to confront the symbiotic relationship between racism and capitalism with White racial supremacy as a causal factor. In the context of Empire, the question is not about the death of humanity, but the death of black African humanity for the life of humanity. Unmasking Christianized fetishes of neoliberal structures that have the capacity to absorb the whole body, Black Theology of liberation, by locating itself in zones of the will to live by the life-lessened oppressed, is a theology of life, the paper argues.
\end{abstract}

Key Words: anti-hegemonic; fetish; management;

\section{Introduction}

If for one moment, Apartheid in South Africa is perceived as the zenith of the Western justificatory logic of racial violence and oppression and the imperialist phase of "primitive accumulation" that dispossessed the material and spiritual resources of black Africans through colonialism and Christianization, then the task of Black Theology of liberation as a discourse of life should be easy to grasp. If indeed Apartheid is for one moment rated as the second most bodily atrocious and horrendous historical experience to Nazi Germany and the holocaust in the $20^{\text {th }}$ century, then the designation "global Apartheid" to the dominant and hegemonic neoliberal order must then be affirmed as correct. 
Indeed, if the collapse of the Berlin Wall, the USSR and the demise of Apartheid demarcate an order that some designated the "end of history," ${ }^{1}$ the insistence of Black theology of liberation on debunking the metaphysics of capitalism with its nascent neoliberal expressions of Christianized fetishes remains authentic a quest for the restoration of human consciousness and the dignity of the whole creation.

The development of Black Theology of liberation in South Africa led among other things to a deep understanding of the relationship between race and economic exploitation. Broadly speaking, as a discourse that irrupted from within the underside of modernity, ${ }^{2}$ locating itself within the experiences of suffering and the struggle history of the racially subjugated, Black Theology of liberation, like Dalit, Minjung, Womanist and Latin American brands of liberation, is quintessentially a theology of life. In our quest to harnessing life-giving resources for the development of an alternative civilization in the context of Empire3, the 'rootage' of this school within the praxis of the poor and the marginalized, remains a pertinent faith orientation and ethic toward life. The history of Black Theology of liberation is thus not intended in this paper, but its appropriation as a theology of life within the racial ponderings of the neoliberal ideology. Second follows a brief interpretation of the opacity of the death dealing spirit of Empire with its manifold challenges to life.

\footnotetext{
${ }^{1}$ See Francis Fukuyama 1992 .The End of history and the Last man. New York: Free Press.

${ }^{2}$ See VS Vellem, up-coming, "From Mission to Stewardship: The Social Analysis of Black Mission in the Context of Empire." In this paper, albeit not exhaustive, the author argues that Black Theology of liberation is a festering underside of the 'Age of Europe' that includes the package of modernity, Reformation, capitalism, science and so forth, which were experienced as violent slavery, racial and economic dispossession and oppression by black Africans.

${ }^{3}$ The term Empire is used as defined by the Accra Confession. In my reading of the WCRC-WCC-CWM discourse, Empire signifies a deadly convergence of economics, politics, and arts with military violence. It is essentially about the violent, militaristic defence of one economic order which subjugates all life under its ideological slants. For works that deal with the Accra, see footnote 2 in VS Vellem 2012. "The Opiate of neoliberal Globalization and the Dawn of Democracy in South Africa" in Theologia Viatorum, volume 36.1., 7693. See also Boesak, A. \& Hansen, L. 2009. Globalisation- The Politics of Empire, Justice and the Life of Faith. Stellenbosch: Sun Press
} 
Proceeding briefly with a re-assertion of Black Theology of liberation as a theology of life, the paper provocatively makes un-concluding remarks about the failure of persuasion among others as an option to engage racism in its relationship with Empire and its morality of death.

\section{The Racial Ponderings of Capitalist and Neoliberal Economics}

One of the most interesting phases in the development of Black Theology of liberation in South Africa was the debate between those who perceived race as the key hermeneutical starting point of the analysis of the struggle against oppression and others on the other hand who emphasised a materialist or class interpretation or economics as a key lens of the analysis of this struggle. ${ }^{4}$ The distinctions emerging from the various strands of Black Theology of liberation is a matter I have discussed in a number of works. Having espoused a comprehensive reading of the school, thus a comprehensive response to the Europeanization of the African continent, colonialism and Apartheid, I suggest that we proceed from an understanding that racism is not only a defect of Eurocentric categories of knowledge construction, including the management of economics. In addition rather, the raison d' être of white supremacy structurally finds expression in racism and modernity itself. ${ }^{5}$ Stated otherwise, the anatomy of whiteness is racism. As indicated in the Introduction of this paper, the past and present struggles against racism in South Africa in particular require this

\footnotetext{
${ }^{4}$ The earliest discussion of this debate is found in Mosala \& Tlhagale 1986. The Unquestionable Right to be Free. Johannesburg: Skotaville. Khabela 1992." A Seamless Garment: Tutu's Understanding of the Role of the Church in South Africa. Unpublished Ph. D. thesis, Union Theological Seminary, takes this up and in a number of his writings Vellem, e.g. 2007 "The Symbol of Liberation in South African Public Life: A Black Theological Perspective," Ph.D. thesis, Dept of Systematic Theology and Ethics, University of Pretoria, Pretoria, alludes to this point. It is worth noting that these two aspects, race and economics cannot be dichotomized, at least in the lived experience of black Africans in South Africa at most.

${ }^{5}$ This point is argued already in the recent analysis of the church's role in relations to the economic policies of the South African government post 1994, see Vellem, V. 2013. “A critical black analysis of the Church's role in post-Apartheid struggle for socio-economic justice” in Studia Historiae Ecclesiaticae December 2013, XXXIX (2), 113-130
} 
comprehensive view of the relationship of race and economics within the historical tragic myth of white superiority.

It is impossible to grasp how the progress of humanity that is so celebrated in Western epistemological texts could be attained by keeping others in dungeons, plantations, mission stations, gas chambers, Robben Island and deep in the belly of our mother earth as cheap labourers without seeing racism as the telos of white supremacy-a metaphysical structure in the European and ipso facto, Western management economics, the West itself being the centre of the world. One cannot but insist that as an effect of the management of White supremacy over other nations, capitalism candidly lives in symbiotic relationship with racial exploitation as the history of "primitive accumulation" (Mosala 1989 ) explicitly demonstrated in the history of South Africa and the African continent at large. Enrique Dussel argues the same point when he lists "Capitalism, liberalism, dualism" as "effects of the management of this function that corresponded to Europe as a "centre" of the "world system"' (2003:66). What Dussel should have added is racism as all of these: capitalism, racism, dualism, liberalism are effects-structural consequences - of the same cause and core value of whiteness, namely, the supremacy of the White race.

The relationship of race and economics in the analysis of Black Theology of liberation is not only apparent in the systematic stages of the development of the school. For example James Cone quite early had this to say:

We cannot continue to speak against racism without any reference to a radical change in the economic order. I do not think that racism can be eliminated as long as capitalism remains intact. It is now time for us to investigate socialism as an alternative to capitalism (1980:16). 
I can anticipate what the last sentence of this quotation might prompt in other minds. The debate between capitalism and socialism is not my intention at the moment. Not that I do not hold any views about them especially when I think about Terry Eagleton's recent work: Why Marx was Right and the marvellous works that have proven the unsustainability of neoliberal capitalism within the ecumenical moment. ${ }^{6}$ Let us hear Cone once again:

The uniqueness of black oppression is not to be understood theologically as if blacks are elected by God but only scientifically. It is a fact that most people who suffer in the world are people of color and not European. And it is a fact that the people responsible for that oppression are white Europeans. Marxists have to be open to hear the meaning of that fact by asking whether fascism is inherent in the very nature and structure of western civilization (1980: 28).

Perhaps the situation has changed and now Europeans like blacks in the past are suffering. The reason why Cone's views on capitalism and Marxism surely expressed more than thirty years ago are important is that in its origins Black Theology of liberation did not turn a blind eye on this-the relationship between racism and economics. I brought this voice to demonstrate that across the Atlantic, the pioneer of the school of Black Theology of liberation made this connection between racism and capitalism very early and indeed posed this question also to Marxists. Importantly, one should say the 'original' defect of capitalism is racism notwithstanding the omnipresence of neoliberal capitalist oppression across races today. Cornel West does the same thing almost at the same time in 1979 when he underscores the indispensability of Marxist thought for the task of Black Theology of liberation to unmask the falsehoods of capitalist society (1979:553-564). In the same manner, the "double jeopardy" of black African women is according to Frances Beale (1979:368376) a direct result of capitalism's destruction of the black race as a whole.

\footnotetext{
${ }^{6}$ This is how I interpret the AGAPE-Accra-Oikotree discourses of the ecumenical movement.
} 
Most recently, Katie Cannon reflects on the same issue in the chapter entitled "Racism and Economics" and poignantly says:

The virulence of modern racism gets its distinctive shape from the capitalist structure of labor exploitation. The suppression and mistreatment of Black people is maintained despite its malevolence and its moral dubiousness because it serves the needs of this system. Racism rationalizes the enslavement of and oppression of people of color. The racial supremacy of Whites is a lie that keeps its legitimacy because it has been used, widely and profitably, to justify the subjugation of people of color on grounds that they are inherently inferior (2011:20).

Cannon goes back to the work of Oliver Cox because in Cuba and Nigaragua racism is unbelievably so, not fully transcended. Cone poses the question to Latin American liberation theologians. South African Black Theology of liberation for a number of years streamed out in two major camps, the racial and materialist strands, against Western orthodox theologies prevalent in Settler and Missionaries models of ecclesiology. In one of the EATWOT's Conferences this matter also had to be painfully dealt with. Among others, the report on EATWOT's proceedings released in 1987 says this:

The issue of race was a particularly painful one to deal with, especially by people from Latin America where on surface there seems to be no racial problem. But the fact that there are few members who are Black and Native America Indians is indicative of the reality of racism in Latin America, especially in Brazil where the population is more than $60 \%$ black. EATWOT assembly resolved to freeze the membership of Latin America until one-third is black and/or Native American (1987:59-59).

I do not go into lengths about this matter for no apparent reason. Racism in South Africa is still alive to add another country to Cannon's list. I am not sure if there has been any epistemological change in Barak Obama's America since the Civil Rights Movement and the recent Ferguson saga.

6 | P a g e 
Racism is still a question in South Africa after more than two decades of democracy as there are clear beneficiaries of colonialism and Apartheid along racial lines. One thing seems to be important here, and Katie Cannon brings it out so well. It is "The racial supremacy of the Whites" as a myth that has been employed to legitimize the subjugation of black people that is at the core of the capitalist structure of modernity. Together with capitalism, liberalism and dualism, effects of the same core value of the centrality of the West in the world, racial supremacy and capitalism share a symbiotic structure of violence and exploitation of the black Africans. From the perceptive of Black Theology of liberation, the analysis of neoliberal economics without the lens of racial supremacy may not be helpful-this said euphemistically. These words by Eduardo Mendieta, in the foreword of Dussel's work entitled Twenty Theses on Politics should adequately grasp the rationale of our argument:

The abolition of the political is thus the negation of human life, not just as naked existence but as collective, communitarian, dialogical, communicative freedom. Without others, without the other, there is neither ethics nor politics. Without others, without the other, there is no politics as the horizon of the possible-the possibility of continued existence. It is this continued existence as coexistence, as surviving and flourishing with others, that is the source of the political. It is this politics that is being abolished by the profiteers of global war and neoliberal pillage. Against this necropolitics of neoliberal globalization, a politics of life, and for life, a politics of life with others and for others [is advocated in this paper] (2008:2of 6).

In other words the argument here is that Black Theology of liberation has been and continues to be a discourse of politics of life and for life and life with others and for others against the historical negation of black human life which has continued beyond 1994 in South Africa in the current neoliberal context which is devoid of racial ponderings. 


\section{The Opacity of Empire}

If there is anything that continues to bedevil South African public life post 1994, it is the embarrassing truth about the vestiges of colonial and Apartheid South Africa finding expression still along racial lines. The "uneven levels of improvement" (Muller 1999) in South Africa after political liberation still reflect a history of racial exclusion and privilege written on the bodies of men and women who are poor and worse in their conditions after twenty one years of democracy. The list in this regard is endless. For sure, we need to coin this question in a particular manner to save time and space. After the demise of Apartheid in South Africa, the problem of democracy is not the problem of humanity, but the problem of democracy and the blackness of humanity. ${ }^{7}$ It is important to understand that Black Theology of liberation distinguishes between democracy as a continuation of racial ponderings and economic exclusion by other means than war and democracy as continuation of life and the restoration of black humanity (cf. Mendieta 2008: 6 of 6). ${ }^{8}$ From this perspective, the adoption of neoliberal economic policies since the demise of Apartheid, leading up to the current promises enshrined in the National Development Plan, shockingly display at foundational level, the metaphysics of economic management based on racial exclusion, extraction and violence. ${ }^{9}$ As Roderick Hewitt (2014) has eloquently argued, a democracy run by syndicates cannot bring any meaningful changes to the lives of the poor.

Yet the pact between white capital and black political power is glaringly indisputable today.

\footnotetext{
${ }^{7}$ I take my cue from the likes of Fanon and Mosala, Fanon and others in this regard.

${ }^{8}$ I have paraphrased words by Mendieta: "To the Clausewitzianslogan that war is the politics is the continuation of war by other means ( as Michel Foucault argued)...politics is the continuation of life through the means of deliberation and delegation whose aim is the very preservation of the opponent" (2008:6 of 6).

${ }^{9}$ For more of my arguments in this regard see Vellem, V 2013, "A critical black analysis of the Church's role in post-Apartheid struggle for socio-economic justice" and 2014. "Modern Slavery in post-1994 South Africa? A critical ethical analysis of the National Development Plan promises for unemployment in South Africa."
} 
It is not a pact of reconciliation between white capital and black power, but one of black power having to be the face of white capital if one has the Marikana Massacre in mind that will continue to haunt our South Africa post 1994. At the level of life in public life, while there are whites that are becoming poor as the gap between the rich and the poor is widening-a similar trend on the globe too- no one can dispute that as beneficiaries of colonial and Apartheid regimes, white South Africans remain much more privileged than black South Africans even today. Anyway, does the fact that whites are poor today become adequate enough to delink racism from capitalism? Like pigs that devour their own, capitalism is not different, it is savage at core. Very little was lost by white South Africans since Mandela, Mbeki, Motlanthe and Zuma were in power. This is no retributive assessment of the problem, but the inability of racial beneficiaries to die voluntarily at the benefits accrued through the exploitation of others for centuries. Tutu's call for a wealth tax after some years of public witness in democratic South Africa is one example that speaks loudly about the fragile promise of political power that has left the foundations of economic management untainted since the demise of Apartheid. While others have continued to discuss the pros and cons of the wealth tax, what they overtly or subtly overlook is the deep question that Tutu has raised in this regard: 'a lack of magnanimity.' The pact between capital and black political power needs a deeper examination than I have done so far. Simply put, it is a continuation of war against black humanity and life by other means.

Franz Hinkelamert's work (1986) is and insightful argument among others that sketches the anatomy of capitalist institutions through the theory of fetishism (Ibid: xiii). He argues that capitalism as a state religion is not easy to discern. It is very difficult to unmask capitalism because it is able to absorb the life of a human being and for this reason, only when one has to contend with the fact that "it is capital that gives bodily existence to the fetish" (1986:xiii) that one can begin to analyse it. But what is a fetish then? It is the spirit of institutions. It is about the experience of these powerful marauding spiritual forces that destroy even those who obey their laws. ${ }^{10}$

\footnotetext{
${ }^{10}$ See Vellem , V 2014." Life-Giving Assets at a Johannesburg Informal Settlement: Black Faith and the False Gods of Multiculturalism in the Twenty First Century,"
} 
Yet those who are consumed in the spirit of the capitalist institutions live large no matter how they destroy life. In this context faith simply becomes that power and will to live. Against forms of theological imaginary that Christianize the fetish of capitalism Black Theology of liberation challenges the opacity of Empire head on. It questions the arrogance of Western theological imaginary as a ploy to harden the husk Empire. As a discourse that debunks racial supremacy-White supremacy- at its foundational level, the following questions in Cone's recent work are pertinent. Cone painstakingly engages the theology of Reinhold Niebuhr and laments among other things that "Niebhur had "eyes to see" black suffering, but I believe he lacked the "heart to feel" it as his own" (2011:41). Cone continues, "It has always been difficult for white people to empathize fully with the experience of black people. But it has never been impossible" (2011:41). Well, I do not need to suspend you any longer now. Here is the crux for me:

But if the lynching tree is America's cross and if the cross is the heart of the Christian gospel, perhaps Martin Luther King Jr., who endeavored to "take up his cross, and follow [Jesus]" (Mark 8:34) as did no other theologian in American history, has something to teach America about Jesus's cross (2011:65).

Cone's serious engagement with Niebuhr almost forty years after the irruption of Black Theology of liberation is extremely invaluable. He poses one of the most penetrating questions, not necessarily new, but perhaps with such force that one who follows this argument cannot but ask: will the centrality of Western epistemologies in theology help theological discourse to transcend racial supremacy? Indeed this question is not new if one thinks about the Belhar Confession and the WCC Programme to Combat Racism. Indeed, if Dietrich Bonhoeffer in Germany and Beyers Naude in South are examples we ever had of white people who denuded themselves of white racial supremacy, is there no other? The opacity and obstinacy of Empire is located in theological imaginaries that serve the fetish of capitalism in South Africa. Such theological imaginaries downplay the symbiotic, violent relationship between racism and capitalism. 
Nothing on the other hand is more devastating than the destruction of human consciousness as expressed in Christianized inferiority complex. These are a fertile market for the gospel of prosperity, hedonistic culture, fetishized and commodified life. If Gutierrez argues that poverty is death, he rightfully argues too that cultural death is the killing of life (2007). Empire destroys the consciousness of the poor; it absorbs the lives of the poor. Empire makes the poor and the rich share the same dreams. The relationship between race and capitalism attains the death of consciousness among the poor in scales no other institution can ever match. This too, is not difficult to argue. What is more difficult to even comprehend is whether Western theological epistemology, while it has "eyes to see" the Marikana Massacre, also has the epistemological capacity to "feel the pain" of the disembowelment of the black person for more than three centuries.

\section{Black Theology of Liberation: A Theology of Life}

It might be easy for anyone to argue that characteristically, the paradigm of liberation in theology is undeniably a pro-life discourse of doing theology. For others it might not be so. To designate any theology as a theology of life is highly contested. For this reason one should not be understood to be blowing one's horn here. To clarify this contestation let us put this matter this way: theology is a discourse of life, but not every theology is a theology of life. This is the paradigm:

Ethical critique commands that we look at our ethical system from the location of its specific victims. Every ethical system cannot but exclude some who are affected by the very performance of that system's goals and expectations. Thus anti-hegemonic ethical critique demands that we critique the system of intersubjective validity from the perspective of the voice of those who are not heard and the claims of those who are intentionally or unintentionally excluded from our ethical deliberation (Mendieta 2008: 4of 6) 
Black Africans are victims of racial capitalism and modernity as a whole. Black Theology of liberation is an anti-hegemonic critique of capitalism, white supremacy, neoliberal ideology, neoliberal democracy and seeks valorises the "catastrophic" experience of those excluded and now killed by the current civilization. It must follow from this then that it is not so obvious to make a claim for a pro-life theology notwithstanding dismissive views from the critics of the liberation paradigm itself. As a second act, reflecting on the praxis of the marginalized and oppressed, some of the concepts that have been used in Black Theology of liberation can explain the orientation of this school to life. If one takes into account the fact that Black Theology of liberation in North America had an intrinsic relationship with Black Power, while the same in South Africa is impossible to understand without Black Consciousness, the question then could be what is the connection of Black Power or Black Consciousness to life?

The Greek word for power bia, is so related to another one for life, bios. Without belabouring the point, this relationship between these two words simply suggests that power is life, consciousness is life. The relationship between Black Theology of liberation and Black Power is thus a relationship between Black Theology of liberation and 'lifeless black life' we need to note this paradox. In the same manner Black Consciousness in South Africa is a concept that speaks to the lifeless life of blacks in so far as their death of consciousness implies the total absence of life in their condition of embodied or bodily oppression. Understood in this way therefore, the relationship between Black Theology of liberation and Black Power and Black Consciousness places Black Theology as life-giving. Stated otherwise, the reality and experience of powerlessness or death of consciousness in the harsh and crushing conditions of the lived-space of the black persons is the reality of death, living death, while the affirmation of the power and consciousness of black people is the affirmation of life. As an anti-hegemonic discourse, Black Theology of liberation is thus a theology of life.

It should be clear that the overall vision-the archaeology of the liberation paradigm in theology is thus the affirmation of life and again not just any life, but the lives of those 
who are literally and virtually lifeless. This is one of the distinguishing features of this paradigm, the affirmation of disconfirmed, lifeless lives as a starting point of doing theology. Inevitably, the orientation of Black Theology of liberation and other theologies of liberation to life is their irruption in crises-crises of life. As one of the exponents of this school, Tinyiko Maluleke aptly argues, Black Theology of liberation lives on crisis. Indeed no one could underestimate the crisis in which Martin Luther Jr., Dietrich Bonhoeffer, Oscar Romero to mention, but a few faced in their doing of theology - a crisis of life and death! Democracy in South Africa brought no crisis to the beneficiaries of Apartheid. It has worsened their crisis to live-and to live so abundantly.

One of the deadliest weapons of the religiosity of Empire is to dichotomize reality. There is a difference between differentiation and dichotomies. The interpretation of the gospel with a dichotomizing epistemological framework keeps the poor dying, while exhorting them to wait for heaven. It throttles and dismembers the body of the oppressed, while promising the salvation of the spirit. The Christianization of this dichotomizing epistemological framework places the gospel of Jesus Christ squarely into the fetish of neoliberal religiosity. Neoliberal religiosity lives on the spirit of the poor, but does not feed the spirit of the poor. Neoliberal religiosity engages in bodily sex with the poor but does not feed and satisfy the sexual desires of the poor. Neoliberal spirituality bodily employs and extracts living work from the poor, but it does not provide life for the poor. Neoliberal religiosity sees the second part of the poor; it does not see the whole body of the poor including their cosmology first.

To this epistemological dissonance, Black Theology of liberation comprehensively embeds itself in the lived spaces of death among the poor and extends its contours to affirm those disconfirmed acts of faith seen as other by a Christianized dichotomy of believers and non-believers. This is how we should view the relationship of Black Theology of liberation with the ethic of Ubuntu. Its embedded-ness in the lived spaces of the African Initiated Churches, the ghettos, the squalid informal settlement is 
enlivened itself by spiritualties of sanity in conditions of imposed insanities of squalor and living death.

\section{Un-concluding thoughts}

I pitched the conversation of this paper at the beginning by illustrating that Apartheid is not unique to South Africa, but a logic falling squarely within the justificatory, dualistic, opaque and death dealing epistemological provenance of the centre which is Europe. While the centre might have been contested, albeit violently in the past, today it is genocidal as racism is virulent for as long as neoliberal capitalism rules the world. Paradigmatically, Black Theology of liberation is an anti-hegemonic discourse valorising victims of racial capitalism and exclusion from political participation in South Africa post 1994.

Exclusion is probably not the major problem as there is an ostensible participation of the elite in the neoliberal economic dispensation both in South Africa and in the world however the pact between capital and black rule in our land does not translate into politics of life. Rather is at the heart a politics of the negation of life. Most importantly, the analysis of the current dominant order of economics is inadequate if the original sin of capitalism-racism-is overlooked when other death dealing effects of the system are engaged to debunk this necropolitics of neoliberal globalization.

\section{References}

Beale, F 1979. Double Jeopardy: To Be Black and Female," in Cone \& Wilmore Black Theology. A documentary History, 1966-1979. New York: Orbis. pp.368-376.

Boesak, A. \& Hansen, L. 2009. Globalisation- The Politics of Empire, Justice and the Life of Faith. Stellenbosch: Sun Press 
Cannon, K. G. 2011. "Racism and Economics: The Perspective of Oliver C. Cox," in Cannon, K.G.; Townes, E. M. \& Sims, A.D. (eds.) Womanist Theological Ethics: A Reader. Louisville Westminster John Knox Press, 3-21.

Cone, J.H. 1980. The Black Church and Marxism: What do they have to say to each other (e-book). New York: Union Theological Seminary..

Cone, J.H. 2013. The Cross and Lynching Tree. New York: Maryknoll, Orbis.

Dussel, E . 2003. Beyond Philosophy, Ethics, History, Marxism and Liberation Theology

Dussel, E. 2008. Twenty Theses on Politics. (Trans by Ciccarielo-Maher, G). London: Duke University Press.

Eagleton,T. 2011. Why Marx Was Right. New Haven \& London: Yale University Press.

Fukuyama, F 1992 .The End of history and the Last man. New York : Free Press.

Gutierrez, G Liberation Theology in the Twenty-Frist Century, in Hogan, J.P \& Closkey, P. H. Romero's Legacy: The Call to Peace and Justice (E-book). New York: Rowman \& Littlefield Publishers.

Hewitt, R. R. 2014. Spirituality for democracy: Spiritual resources for democratic participation in the $21^{\text {st }}$ century, Verbum et Ecclesia 35 (3), Art. \#1345, 7 pages. http://dx.doi.org/10.4102/ve.v35i3.1345.

Hinkelammert. F. J 1896. The ideological weapons of death: a theological critique of capitalism /; translated from the Spanish by Philip Berryman. P Maryknoll, N.Y : Orbis

Khabela, M G. 1992. A Seamless Garment: Tutu's Understanding of the Role of the Church in South Africa. Unpublished Ph. D. thesis, Union Theological Seminary

Maluleke, T 1995 "Black Theology lives! On a permanent Crisis", in Journal of Black Theology in South Africa. Vol.9. No.1, pp.1-30.

Mendieta. E. 2008. Foreword in Dussel, E. 2008. Twenty Theses on Politics. (Trans by Ciccarielo-Maher, G). London: Duke University Press, pp. 1-6 (electronic copy). 
Mosala, I \& Tlhagale, B.1986. The Unquestionable Right to be Free. Johannesburg: Skotaville.

Muller, C. 1999. Rituals of fertility and the sacrifice of desire : Nazarite women's performance in South Africa. Chicago : University of Chicago Press, 1999.

Report on The Second General Assembly of The Ecumenical Association of Third World Theologians (EATWOT), Held in Oaxtepec, Mexico, December, 1986" in Journal of Black Theology in South Africa.Vol.1No.2, pp 54-59.

Vellem, V. 2007. " The Symbol of Liberation in South African Public Life: A Black Theological Perspective," Ph.D. thesis, Dept of Systematic Theology and Ethics, University of Pretoria, Pretoria

Vellem, V. 2012. "The Opiate of neoliberal Globalization and the Dawn of Democracy in South Africa" in Theologia Viatorum, volume 36.1., 76-93.

Vellem, V. 2013. “A critical black analysis of the Church's role in post-Apartheid struggle for socio-economic justice" in Studia Historiae Ecclesiaticae December 2013, XXXIX (2), 113-130.

Vellem, V. 2014. “Life-giving assets at Thabo Mbeki Village: Black faith and the Baal's of Multiculturalism in the 21st Century" in Smith, D, Ackah, W and Reddie, G. Churches, Blackness, and Contested Multiculturalism. New York: Palgrave MacMillan.

Vellem, V.S., 2014, 'Modern slavery in the post-1994South Africa? A critical ethical analysis of the NDP

promises for unemployment in South Africa', Koers - Bulletin for Christian Scholarship 79(2), Art. \#2163, 8 pages. http://dx.doi.org/10.4102/koers. v79i2.2163

West, C . 1979. “ 1979. Black Theology and Marxist Thought,” in Wilmore, G.S. \& Cone, J.H. Black Theology. A documentary History, 1966-1979. New York: Orbis. pp.552-567.

Wright, N. (Jnr.) 1979. "Black Power: A Religious Opportunity," in Cone \& Wilmore Black Theology. A documentary History, 1966-1979. New York: Orbis. pp. 48-61. 